\title{
O BREVE TEMPO DE SER \\ DUAS VELHICES E ALGUNS FLAGRANTES DE FELICIDADE
}

\author{
Claudia Barbosa de Medeiros é mestranda do curso de Literaturas Portuguesa e Africanas da UFRJ, com a pesquisa voltada para a \\ produção literária do escritor moçambicano Mia Couto. \\ E-mail: cbmedeiros@terra.com.br.
}

\section{Resumo}

Este artigo propõe-se a analisar o cotidiano de dois velhos, protagonistas em contos de Mia Couto, buscando aproximações e, sobretudo, oposições entre ambos, flagrando imagens distintas de felicidade.

\begin{abstract}
Resumen
Este artículo se propone a analisar el cotidiano de dos ancianos, protagonistas em los cuentos de Mia Couto, buscando similitudes y, sobre todo, oposiciones entre ellos, identificando distintas imágenes de felicidad.
\end{abstract}

Toda saudade é uma espécie de velhice.

Guimarães Rosa

Tornar-se velho é o irremediável caminho de quem se deseja longevo, daquele com pretensões de uma existência duradoura, seja por amor a si ou a outros, seja por ambição de empreender realizações, seja por ambos. Envelhecer é o desagrado desejável, a única experiência a nos manter distantes da morte que, para Georges Bataille, "é a violência maior, pois nos arranca da obstinação que temos em ver durar o ser descontínuo que somos." (1968, p.18).

Entretanto, a duração extensiva da vida cobra o preço e a velhice, quase sempre, aplica pesado ônus ao sujeito. Mais atingido, o corpo entra num acelerado processo de degeneração, perdendo vigor em suas funções físicas e cerebrais. Da fragilidade corporal, grande causadora de insegurança e intensificadora do medo, decorre um abalo no equilíbrio psicológico e o indivíduo passa a lidar com limitações concretas, maiores ou menores, no exercício diário de sua liberdade. Com a perspectiva de futuro cada vez mais estreita, as grandes angústias existenciais mudam o foco: é sobre a não-existência que se fundam os tormentos.

Do ponto de vista da vida social, recorrentemente os velhos são excluídos, sobretudo quando está em jogo a face econômica de uma sociedade. Estabelecer-se em empregos, sendo um gerador de bens e de capital, é raro, diante da ideologia capitalista 
que reveste grande parte do mundo. Como mortes simbólicas, essas perdas acumuladas produzem uma velhice demasiado velha. Sobre isso, fala-nos Ana Maria Ferreira:

Todos morremos progressivamente; a morte é um processo não um estado. E em última análise a nossa vida é o período de tempo que levamos a morrer. A velhice é já a morte. Morte social e socioeconómica daqueles que perderam todo o seu prestígio ou a sua capacidade produtiva. (Ferreira, 2007, p. 315)

Diante da velocidade que a época atual imprime à vida, a bagagem cultural acumulada pelos velhos normalmente também não encontra espaço na estrutura social para ser transmitida. Dessa forma, a "voz da experiência" acaba distanciada de potenciais ouvidos e silenciada no tempo veloz.

Para Simone de Beauvoir, a condição de ser velho possui uma dualidade intrínseca, a dizer: uma face exterior que classifica o idoso como categoria social de um determinado contexto histórico e uma face interior, ou seja, as particularidades, o pulsar do indivíduo, suas motivações e as imagens de si:

Consideramos o homem idoso enquanto objeto da ciência, da História, da sociedade: descrevemo-lo em exterioridade. Ele é, também, um sujeito que interioriza sua situação e que reage a ela. Tentemos entender como ele vive sua velhice. A dificuldade é que não podemos adotar, com relação a esta, nem um ponto de vista nominalista, nem um ponto de vista conceitualista. A velhice é o que acontece às pessoas que ficam velhas; impossível encerrar essa pluralidade de experiências num conceito, ou mesmo numa noção. Pelo menos, podemos confrontá-las umas com as outras, tentar destacar delas as constantes e as razões de suas diferenças. (Beauvoir, 1990, p. 345)

A expressão "pluralidade de experiências" traduz a ideia essencial deste artigo, uma reflexão sobre o contexto social e as motivações que envolvem os velhos protagonistas dos contos Nas águas do tempo e Noventa e três, de Mia Couto, cada qual em sua vivência particular. A mesma expressão também poderia ser utilizada na própria definição do conceito de felicidade, em que pese sua conotação polissêmica e a relativização de valores inerente à condição de ser feliz. Afinal, a cada ser a justa medida daquilo que lhe dá prazer.

Se a longevidade da vida, pouco a pouco, impõe restrições ao velho, ele, como categoria social, também não as deixa de ter. Vencer a morte, estendendo a vida, tornase uma batalha não somente contra o tempo, mas também sobre os valores que formatam o nosso pensamento social, principalmente se buscamos aliar qualidade à quantidade de anos que a vida pode nos presentear. Ou seja, acrescentar anos à nossa vida deveria significar, irremediavelmente, somar vida aos nossos anos.

É sobre esta contradição de valores, própria da condição humana, que nos fala Mia Couto nos contos Noventa e três e Nas águas do tempo, sobre os quais nos debruçaremos neste trabalho. Investigaremos alguns de seus quadros narrativos, numa perspectiva comparada, para que, numa interpretação da velhice desenhada em cada um 
dos textos, possamos fazer uma captação das imagens da presença ou da ausência de felicidade nas histórias analisadas.

\section{1) Mia Couto: um breve sobrevoo}

Os textos Nas águas do tempo e Noventa e três estão inseridos em seu livro Estórias abensonhadas, obra de 1996 e que traz em seus contos as contradições políticas e sociais de uma Moçambique recém-independente de Portugal. Saído de um duro e extenso processo de colonização, cuja independência foi conquistada com o alto preço de uma guerra, logo seguida de outra, a civil, que duraria dezessete anos, o país, ao final do século XX, divide-se entre o drama da perda e do abandono, em decorrência dos conflitos bélicos, a miséria instituída e a urgência em reconstruir-se, recuperando suas referências culturais e fortalecendo sua economia. Um país dividido entre a violência sangrenta de um passado recente e o sonhar inéditos futuros, entre "as margens da mágoa e da esperança", no dizer do próprio autor na apresentação da obra. Ao tratar do particular, de questões locais, Couto elabora uma escrita ficcional em que recupera identidades culturais ao mesmo tempo em que a tece a partir de temas universais como a ânsia pela liberdade, a esperança diante das vicissitudes e a viabilidade do amor nas relações contemporâneas.

A obra narrativa de Mia Couto é, marcadamente, comprometida com dois elementos: um estilístico e outro temático. O primeiro é o sentido poético que imprime a suas narrativas, formatando-as num tom predominantemente lírico, em que as palavras se vestem de conotações várias e se recriam e se reinventam no nível do léxico, da sintaxe, da morfologia e da semântica. O segundo elemento presente recorrentemente na narrativa coutista é o resgate das tradições de Moçambique, país de origem do autor, das marcas fundadoras de suas múltiplas culturas, da riqueza de seus símbolos míticos e sociais, afirmando, dessa forma, seu lugar no mundo.

A linha a costurar o estilo poético ao eixo temático voltado para as riquezas de uma moçambicanidade trazida à luz depois de séculos de apagamento em decorrência da opressora colonização vivida é o olhar crítico do autor que sendo um prosador-poeta é, ao mesmo tempo, moçambicano e cidadão do mundo, constituído de elevada consciência social. Dessa confluência, nascem textos que fazem um retrato poético, alegórico e crítico da Moçambique contemporânea, inserida num mundo globalizado e globalizante, economicamente enfraquecida e que ainda cicatriza as feridas da mão-deferro portuguesa e da recente guerra civil. Equilibrando passado e presente e sonhando futuros, o real e a fantasia caminham juntos, constituindo harmoniosa matéria-prima literária.

Noventa e três e Nas águas do tempo registram essas marcas dicotômicas entre o passado e o presente, a tradição e o moderno, a memória (coletiva) e o esquecimento, entre o perene e o efêmero e é relacionando a passagem do tempo, o estar velho, com o 
valor da vida e da morte que confrontamos as duas histórias buscando revelar aproximações e, sobretudo, oposições entre ambos os contextos. Partindo do fato social de ser velho na contemporaneidade em que estamos inseridos, refletimos também como tais similaridades ou diferenças tornam singular a inexorável busca por felicidade e prazer.

\section{2) Análise dos contos}

Os contos analisados neste artigo polarizam o lugar do velho na estrutura social, permitindo-nos fazer tais confrontações e investigar onde há pontos de antagonismo ou mesmo de contato. As duas narrativas são protagonizadas por velhos apresentados dentro de um contexto familiar e que, em suas pequenas ações cotidianas, desejam estabelecer sentidos para sua vida diante da passagem irremediável do tempo. Essencialmente, parte da circunstância da velhice para refletir sobre a condição transitória do ser no mundo, apontando as idiossincrasias entre as duas personagens a partir de suas particulares vivências.

Ficcionalizando realidades sociais bastante distintas, Mia Couto apresenta em Nas águas do tempo um velho dotado de prestígio, associado aos antigos valores de África, onde o velho desempenha o papel de guardião da cultura e do saber sagrado: um avô ensinando ao neto a comunicar-se com os mortos, a se ligar a gerações passadas, reverenciando aqueles que passaram a habitar o espaço da ancestralidade. Preocupado com o possível apagamento desta tradição local (resquícios das guerras), o avô teme pelo rompimento deste laço entre os vivos e os mortos: "não posso ser o último a ser visitado pelos panos" (Couto, 1996, p. 12). O neto permanece acompanhando o avô em todas as visitas ao lago onde o rio deságua, na expectativa de ver os acenos com lenços brancos que vinham da margem. Por muito tempo não os viu, sem que, no entanto, perdesse importância a rotineira ida àquele lugar. Até que o sentido se completa e, finalmente, tem a visão de um lenço branco agitando-se em sua direção. É o velho avô morto, mas ainda presente e atuante no seu mundo, no mundo dos vivos, pois a tradição se cumpriu e os canais da comunicação haviam, finalmente, sido fixados.

Já em Noventa e três, o velho protagoniza a representação de uma realidade menos valorosa, em que prevalece a superficialidade nas relações pessoais e onde, remetendo-nos à tendenciosa configuração da sociedade contemporânea sob o comando da ideologia capitalista, a materialidade da vida concorre e ganha da afeição:

Foram entrando um por um. O velho estava na cabeceira, cabeceando. À medida que entravam, alguém anunciava os nomes, descrevendo em voz alta o jeito dos vestidos. Os netos encheram sala, os bisnetos sobraram no quintal. $O$ avô levantava um olhar silencioso, sem luz. Sorria o tempo todo: não queria cometer indelicadeza. $\mathrm{O}$ avô fingia 
aniversariamente. Porque em nenhum outro dia os outros dele se recordavam. Deixavam-no poeirando com os demais objetos da sala. (Couto, 1996, p. 55)

Neste trecho, que é o parágrafo inicial do conto, percebemos a impessoalidade da voz narradora, em terceira pessoa, configurando um texto sem a marca da subjetividade. A citação da presença de muitas pessoas no espaço narrativo não determina que elas, necessariamente, venham a se tornar personagens, com ação e relevância na trama. Ao contrário, os netos e os bisnetos enchem sala e quintal, mas são vazios de importância na relação com o avô. Enchem mas não preenchem. E numa relação recíproca, o avô é tão desimportante para todos ali presentes que, fora o dia de seu aniversário, sua vida nem é lembrada e, sem valor, o velho passa por um processo de despersonalização, de coisificação: "Deixavam-no poeirando com os demais objetos da sala."

Em Nas águas do tempo, o trecho que inicia o conto estabelece as primeiras oposições entre uma narrativa e outra. Num discurso carregado de afetividade, o neto inicia a narração da grande experiência que teve ao lado do avô, em que, agregando aventura e ensinamento, ajudou-lhe a estabelecer o sentido da sua vida:

Meu avô, nesses dias, me levava rio abaixo, enfilado em seu pequeno concho. Ele remava, devagaroso, somente raspando o remo na correnteza. $\mathrm{O}$ barquito cabecinhava, onda cá, onda lá, parecendo ir mais sozinho que um tronco desabandonado.

- Mas vocês vão onde?

Era a aflição de minha mãe. O velho sorria. Os dentes, nele, eram um artigo indefinido. Vovô era dos que se calam por saber e conversam mesmo sem nada falarem. (Couto, 1996, p. 9)

Se Noventa e três e Nas águas do tempo assemelham-se no tipo que protagoniza a história, o mais velho da família, as narrativas distanciam quanto ao espaço narrativo. Enquanto no primeiro conto a trama desenvolve-se dentro do território urbano, variando do espaço doméstico, a casa, onde decorre a primeira ação na qual a personagem tenta interagir com seu núcleo familiar, para o espaço público, a rua, quando o velho deseja evadir-se de sua realidade, em Nas águas do tempo privilegia-se a terra, através da configuração de um espaço narrativo essencialmente natural, como o rio e a floresta, reafirmando a geografia local. Simbolicamente, podemos associar esta amplidão sugerida pela natureza ao projeto de liberdade dos moçambicanos, ao resgate das raízes - ainda mais por ser esse o espaço que abriga a ancestralidade - e a possibilidade de projetar novos futuros.

Se sonhar de certa forma é abstrair-se do mundo real, vislumbrar felicidades em outras esferas, em Noventa e três essa abstração da realidade acontece, não no nível mental, mas na ação concreta do velho que parte para a rua em busca de acolhimento (de estranhos). Em última instância, parte para ser feliz. A casa, o espaço doméstico que serve de cenário para sua festa de aniversário, onde estão seus familiares, torna-se um espaço opressor, esvaziado de sentido, ausente de felicidade - pelo menos para o velho: 
"a multidão, ruidosa, acelera os festejos. Naquela alegria não cabem avôs. As bebidas correm, as mentes se vão tornando líquidas" (p. 57). A multidão era um ajuntamento de pessoas sem intimidade.

Esta significação do espaço narrativo relaciona-se com a função social que o velho tem na família, a forma como ele (não) se insere e o nível de interação que se estabelece, quase nenhum. Aquele espaço privado da casa reflete o encarceramento de que o velho fica refém:

Agora por entre os barulhos que invadiram toda a casa, o avô sente saudade do jardim. Será que pode sair?

- Sair?

Os familiares se admiram, indignados. Então, no preciso dia de anos? E aonde? O velho se resigna, desistido. (Couto, 1996, p. 56)

Seu desejo é de vínculos que se suponham concretos e não aparentes: "Vai encontrar seus dois vigentes amigos: um gato silvestre e Ditinho, o menino de rua, desses que perderam a morada" (p. 56), como ele. Mesmo limitado pela cegueira, seu desejo é vislumbrar vínculos, interagir, dialogar, ter contato físico, como aquele com o gato que "se esfrega, seu todo corpo é uma língua lambendo o velho" (p. 56). O sentimento do velho se dirigia àquelas relações fluidas com dois seres que, como ele, também não tinham função social no mundo. Juntos descobrem uma espécie de utilidade recíproca, e na breve felicidade daquele encontro a sede de pertencimento do velho é aplacada, afinal "só para eles, vadios no jardim, ele se sentia avô." (p. 58). Este difícil equilíbrio entre escolha e parentesco, para Zygmunt Bauman, é improvável devido à natureza distinta de uma e de outro:

A escolha é o fator qualificante: ela transforma o parentesco em afinidade. [...] Seria altamente desejável que o parentesco fosse precedido da escolha, mas que a consequência desta fosse exatamente aquilo que o parentesco já é: indiscutivelmente sólido, confiável, duradouro, indissolúvel. (Bauman, 2004, p. 45)

Em Nas águas do tempo, Mia Couto parece realizar uma aproximação feliz entre afeto e parentesco: a relação entre o avô e o neto é estabelecida a partir da afeição e da confiança. O mais velho constrói novos vínculos para seu descendente, ligando-o aos seres ancestrais, numa ponte que une passado e presente, consagrando e perpetuando as tradições e a memória cultural de um povo. Opondo-se ao cego de Noventa e três, o velho vê além, vê a imagem dos mortos e ensina o neto a se comunicar com eles. Através dele são vividas as experiências mais significativas. Diferente do processo de despersonalização por que passa o outro, este é a personificação da sabedoria e na família, é ele o construtor de novas possibilidades.

O reconhecimento da função social do velho, em certa medida, vem determinar a presença ou a ausência de uma relação mais significativa entre os membros da família, em que haja espaço para o afeto e as ações decorrentes dele, como a intimidade e o 
diálogo. O aniversariante de Noventa e três paira pela festa sem encontrar outro lugar que não seja sua cadeira de balanço, nem algum interlocutor com quem estabeleça uma conversa de mais de duas frases.

O tempo lhe parece fugidio e entre as perguntas que faz para tentar reconhecê-lo, escuta a mesma resposta: noventa e três. Se o número representa sua idade ou o ano presente, ele não sabe. Confuso, sua tentativa de esclarecimento é em vão porque a resposta de vários dentre os presentes, sempre igual, é como uma voz monocórdia: noventa e três. Isolado em suas dúvidas e silenciado na sua insegurança, o velho remete seu pensamento aos seus dois insólitos "amigos", feitos na rua em meio à despretensão dos fortuitos encontros. Amigos com os quais o seu discurso permanecerá imerso no isolamento. Afinal, que diálogo trava-se com um gato? Ou que seriedade comporta a conversa com um menino de rua cuja expectativa pela chegada do outro traz a intenção de apalpar seus bolsos e sua carteira a fim de tomar suas posses? Sobre a importância do discurso, diz Ecléa Bosi: "O instrumento decisivamente socializador da memória é a linguagem. Ela reduz, unifica e aproxima no mesmo espaço histórico e cultural a imagem do sonho, a imagem lembrada e as imagens da vigília atual" (Bosi, 1983, p. $18)$.

É o que ocorre com o avô de Nas águas do tempo, profuso mesmo quando em silêncio, pois "era dos que se calam por saber e conversam mesmo sem nada falarem" (p. 9). Sua capacidade dialógica é tão extensa que seus interlocutores tanto estão no mundo físico, com quem interage verbalmente, quanto no mundo sobrenatural, os ancestrais, de quem ele apreende ensinamentos e mensagens. Para Carmen Tindó,

Os velhos tinham um papel importante nessa filosofia de vida africana: eram os guardiães da memória, os 'griots', ou seja, os contadores de estórias que passavam aos mais jovens os conhecimentos tradicionais. Eram eles, assim, os intermediários que ouviam os antepassados e transmitiam suas mensagens aos humanos. (Secco, 2008, p. 158)

Diante das transformações que a pós-modernidade imprimiu em todo mundo, da configuração política a valores éticos, é possível que esta tradição na África também tenha sofrido certo abalo, embora em Nas águas do tempo, uma narrativa contemporânea, Mia Couto reafirme este traço cultural. Sob esta perspectiva, a trama existencial do velho do conto Noventa e três pode apontar para uma tendência das relações contemporâneas em que prevalece uma "misteriosa fragilidade dos vínculos humanos, o sentimento de insegurança que ela inspira e os desejos conflitantes (estimulados por tal sentimento) de apertar os laços e ao mesmo tempo mantê-los frouxos" (Bauman, 2004, p. 8).

Outra perspectiva que parece antagonizar nas duas narrativas é o tempo. Em Noventa e três, a necessidade do velho em saber o ano em que se está e a idade que ele tem aponta para uma consciência clara da finitude do ser, sua limitação temporal 
relacionada ao envelhecimento do corpo. Sobre essa fragilidade da existência diante do estreitamento da duração da vida, Simone de Beauvoir comenta:

Existir, para a realidade humana, é temporalizar-se: no presente, visamos o futuro através de projetos que ultrapassam nosso passado [...]. A idade modifica nossa relação com o tempo; ao longo dos anos, nosso futuro encolhe, enquanto nosso passado vai-se tornando pesado. Pode-se definir o velho como o indivíduo que tem uma longa vida por trás de si, e diante de si uma expectativa de sobrevida muito limitada. (Beauvoir, 1990, p. 445)

Em Noventa e três, a limitação do ser não esbarra só na convicção de sua finitude. Na vida do protagonista, a ausência de projeto de futuro conciliado ao passado esquecido acaba por gerar a impossibilidade do presente. Já no segundo conto a relação com o tempo é mais visceral: o passado não é só o antecedente do presente, é sua fonte. Se o título Noventa e três remete a um instante pontual da passagem do tempo, seja indicando a idade da personagem ou o ano, no outro conto, a composição do título Nas águas do tempo nos aponta para uma ideia de continuidade, de algo que não se pode deter, um fluxo ininterrupto, o próprio tempo traduzido em essência e não em instante. O que se confirma na leitura da narrativa ao vê-la trazer os mortos para o mundo dos vivos, ou vice-versa, e o rio, em suas águas e margens, sendo o espaço de intersecção entre ambos. Os vivos e os mortos não habitam esferas estanques. Não há o que temer, pois não há o fim, ao contrário, a grande intenção do avô é transmitir ao neto a consciência de que entre a vida e a morte há um fluxo contínuo. De certa forma,

Os projetos do indivíduo transcendem o intervalo físico de sua existência: ele nunca morre tendo explicitado todas as suas possibilidades. Antes, morre na véspera: e alguém deve realizar suas possibilidades que ficaram latentes, para que se complete o desenho de sua vida. (Bosi, 1983, p. 32)

O pensamento de Ecléa Bosi chama atenção para as potencialidades que cabem numa existência e se a morte detém sua expressão não consegue, porém, deter sua intencionalidade. O que ela destaca como "a morte de véspera" pelo o fato de o ser não efetuar em vida todos os seus projetos (ou "possibilidades"), podemos comparar ao que acontece no estágio da velhice do ser humano, quando a intenção de agir, muitas vezes, não acompanha a capacidade para tal. Neste sentido, contrapomos mais uma vez os protagonistas dos dois contos. Se a relação de ambos com o tempo é distinta, a ação deles diante da passagem do tempo é, na mesma medida, diferente, opondo um ser mais passivo diante da vida - e literalmente cego para ela - a outro, extremamente ativo diante da vida e também da morte - cuja visão vai além dos olhos físicos.

Na primeira parte de ambas as narrativas, a seleção dos léxicos verbais já antecipa o posicionamento de cada um. Diante de sua debilidade física e pouco prestígio social, o aniversariante de Noventa e três limita suas ações e assim, sorri para não cometer indelicadezas, finge, cabeceia, ouve e agradece. Enquanto o avô de Nas águas 
do tempo, ágil e influente, leva o neto rio abaixo, rema, conduz, cala por saber e conversa mesmo sem nada falar e é sempre arrebatado pela novidade de viver.

A passividade do velho de Noventa e três não impede, no entanto, que ele a sua maneira busque o prazer e a felicidade. Se por um lado ele se ajusta a um esquema de festa pela comemoração do seu aniversário em que sua presença é meramente figurativa ("Vendo-o assim esplendoloroso, acreditam, para sossego deles, que o avô já tenha adormecido" (p. 55) e ainda "O velho deve estar por aí dormindo, dizem, ele descansa assim no meio de qualquer momento" (p. 57), por outro lado ele se vale de "sua mais secreta malandrice" para exercer sua liberdade, evadindo-se para a rua e, na fuga daquela realidade, concretizar seu projeto de felicidade: andar pelo jardim público, esparramar-se no banco, interagir com seus parceiros e suspirar "uma leve felicidade" (p. 58).

Imagens de felicidade, como vimos, aparecem no percurso dos dois protagonistas, embora para o velho de Noventa e três elas sejam menos frequentes e o que prevaleça na narrativa - sobretudo na primeira ação dramática, o aniversário em família - seja a ausência de felicidade, ao menos para o velho. Muito mais marcantes em Nas águas do tempo, tais imagens de felicidade são a representação de um tempo em que se ampliam as dimensões entre o começo e o fim das coisas e de um lugar onde se ultrapassa margens e se transgride perspectivas. Intervenções literárias, breves epifanias de felicidade.

\section{3) Conclusão}

A fim de descobrir fórmulas e meios que possibilitem ao ser humano uma vida mais duradoura, a medicina avança em suas pesquisas, investindo, mais que tempo e dinheiro, a esperança de todos nós por uma existência longeva e saudável. O que a leitura de Nas águas do tempo e de Noventa e três nos fez desejar também é um mundo que concilie o bem-estar tanto na vida física quanto na vida social: se queremos envelhecer, posto que isso é uma condição inerente a manter-nos vivos, na mesma medida sonhamos com uma sociedade mais humana em que se subverta o mecanismo cruel de exclusão social do velho.

O conto Noventa e três nos mostrou com mais clareza como se dá o processo de limitar a inserção do idoso nos grupos de convívio e sua autonomia diante da vida, mas como tal privação não encerra (ou não encerrou) a disposição de existirmos a partir da reunião de dois princípios: liberdade e felicidade. Ao promover a aproximação dos excluídos (em que pesem as medidas diferentes de tal exclusão), o velho, o gato e o menino de rua, Mia Couto configura uma sociedade imaginária cujos velhos, apesar de tudo, têm inabalada sua busca por instantes de contentamentos e independência, ainda que através de pequenas transgressões. 
As marcas opositoras entre os dois velhos protagonistas de Nas águas do tempo e Noventa e três, apresentadas neste artigo, nos remetem a certo antagonismo intrínseco aos dois estados que fundamentam as personagens de acordo com a nossa abordagem: velhice e felicidade. Se estar velho é um processo involuntário da condição humana, destino irrefutável daquele que deseja vida longa, a felicidade, ao contrário, é uma ação deliberada do ser, estado construído e impermanente, circunstancial por natureza.

Velhice e felicidade separam-se na forma como são instituídas no indivíduo, mas também em suas margens: se a morte é o único ato capaz de deter a primeira, contra a condição de ser feliz é a própria vida, com suas vicissitudes, que intimida e reprime a ação efetiva de sua busca pelo ser humano. Neste ponto habita o legado maior de Nas águas do tempo e Noventa e três, na perspectiva deste trabalho: a comunhão de uma e de outra. Os velhos, apesar das diferenças apontadas em suas relações familiares, em seu (des)prestígio social e em suas motivações psíquicas, perseguem um sentido para a vida, sentido esse que se veste de ocasionais realizações, embora, não por isso, porte menos valor. Seja pela evasão que consola, como em Noventa e três, seja pelo sonho que renova, como em Nas águas do tempo, tais realizações são a experiência da velhice agregada à busca pelo que falta, pelo que ainda pode ser ou vir, pelo que movimenta as pernas a um passo adiante: a felicidade, ou algo muito parecido com isso.

\section{Referências Bibliográficas}

BATAILlE, Georges. O erotismo. Tradução de João Bénard da Costa. Rio de Janeiro: Moraes Editores, 1968.

BAUMAN, Zygmunt. Amor líquido: sobre a fragilidade dos laços humanos. Tradução de Carlos Alberto Medeiros. Rio de Janeiro: Jorge Zahar Ed., 2004.

BEAUVOIR, Simone de. A velhice. Tradução de Maria Helena Franco Monteiro. Rio de Janeiro: Nova Fronteira, 1990.

BOSI, Ecléa. Memória e sociedade: lembranças de velhos. São Paulo: T. A. Queiroz, 1983.

COUTO, Mia. Estórias Abensonhadas. Rio de Janeiro: Nova Fronteira, 1996.

FERREIRA, Ana Maria Teixeira Soares. Traduzindo mundos: os mortos na narrativa de Mia Couto. Tese de doutorado (Literatura). 2007. 560 f. Universidade de Aveiro, Departamento de Línguas e Cultura.

SECCO, Carmen Lúcia Tindó Ribeiro. "Representações da morte em textos literários de Angola e Moçambique”. In: AMÃNCIO, Íris Maria da Costa (org.). África-Brasil- 
África: matrizes, heranças e diálogos contemporâneos. Belo Horizonte: PUC Minas, Nandyala, 2008. 